NBER WORKING PAPER SERIES

\title{
RECENT TRENDS IN RESOURCE SHARING AMONG THE POOR
}

\author{
Steven J. Haider \\ Kathleen McGarry \\ Working Paper 11612 \\ http://www.nber.org/papers/w11612
}

\author{
NATIONAL BUREAU OF ECONOMIC RESEARCH \\ 1050 Massachusetts Avenue \\ Cambridge, MA 02138 \\ September 2005
}

This paper was prepared for the National Poverty Center project, "Working and Poor: How Economic and Policy Changes are Affecting Low-Wage Workers." We are grateful for useful advice from Rebecca Blank, Sheldon Danziger, Robert Schoeni, and participants at the preliminary conference in Ann Arbor, MI. Both authors gratefully acknowledge financial support. Haider from the National Institute for Child Health and Development (R03 HD42084-01) and McGarry from the National Institute On Aging (R29 AG14110-05). The views expressed herein are those of the author(s) and do not necessarily reflect the views of the National Bureau of Economic Research.

(C2005 by Steven J. Haider and Kathleen McGarry. All rights reserved. Short sections of text, not to exceed two paragraphs, may be quoted without explicit permission provided that full credit, including () notice, is given to the source. 
Recent Trends in Resource Sharing Among the Poor

Steven J. Haider and Kathleen McGarry

NBER Working Paper No. 11612

September 2005

JEL No. I3, J0, H0

\begin{abstract}
$\underline{\text { ABSTRACT }}$
Motivated in part by the dramatic changes in the United States economy and public assistance policies, many researchers have examined the changes in the resources of the low-income population over the last two decades, with particular attention paid to income from earnings and public assistance programs. One source of income that has received comparatively little attention is income from private transfers. However, private transfers may be a key source of support for low-income individuals, especially for those who have had little attachment to the labor force or who have experienced reductions in public assistance. In this paper, we provide a conceptual discussion of private transfers drawing on several related literatures and provide new empirical evidence regarding the significance of private of transfers as a source income. We find that private transfers are an important source of income for many less-skilled households, the contribution of private transfers to total income has increased over time, and shared living arrangements are a common mechanism for providing assistance.
\end{abstract}

Steven J. Haider

Michigan State University

Department of Economics

110 Marshall-Adams Hall

East Lansing, MI 48824-1038

haider@msu.edu

Kathleen McGarry

Bunche Hall 9359

UCLA Department of Economics

Box 951477

Los Angeles, CA 90095-1477

and NBER

mcgarry@ucla.edu 


\section{Introduction}

During the 1990s, the United States economy experienced sustained economic growth with low levels of unemployment and high levels of wage growth accruing across the skill distribution. Along with this robust economic performance, there were substantial changes in economic and social policies: the minimum wage was raised for the first time in fifteen years, the Earned Income Tax Credit (EITC) was expanded, and cash welfare assistance was changed from an entitlement to a temporary assistance program that imposes strict work requirements and lifetime limits on benefits.

Many of these changes would be expected to have had large effects on the incomes of the poor, and consequently, there has been a spate of research assessing how the low-income population has fared. Some of these studies have focused on specific changes—such as changes in the wage distribution (David Autor, et al., 2004), the Earned Income Tax Credit (Bruce Meyer and Daniel Rosenbaum, 1999), and cash welfare assistance (see Rebecca Blank 2002 for a useful review) — while others have examined the overall changes in the income of the poor (Blank and Robert Schoeni, 2003).

One source of income that has received comparably little attention is income from private transfers. Private transfers can come from relatives, friends, or non-spousal partners and can consist of cash or non-cash transfers or shared living arrangements. ${ }^{1}$ We refer to this broad definition of private transfers as "resource sharing." Shared resources could be especially important for low-income individuals who may not qualify for benefits from social insurance programs such as unemployment insurance or Worker's Compensation, both of which require some degree of previous attachment to the labor force. Moreover, the recent changes in public

\footnotetext{
${ }^{1}$ Although assistance from charitable institutions may be an important source of support for some low income families, we do not address it here.
} 
assistance programs, including time limits on benefit receipt and work requirements, will result in a reduction in assistance for some. Absent these formal sources of support, low-income individuals may turn to family or friends. Recent research has indeed provided some evidence that resource sharing is an important component of income for individuals leaving the welfare rolls (Sheldon Danziger et al., 2002; Robert Moffitt and Katie Winder, 2005).

In this paper, we consider the importance of resource sharing to the financial well-being of low-income households and changes in this importance over time. We begin in section 2 with a broad discussion of resource sharing, drawing on several existing literatures. We consider both the potential motivation for sharing and the different modes through which such sharing can occur. Because this volume focuses on the low-income population, we pay specific attention to the interaction between private transfers and government assistance programs.

In Section 3 we undertake an empirical analysis of resource sharing from 1980 to 1979 to 2003 using data from the Current Population Survey (CPS). Our analysis yields several important findings. First, private cash transfers from outside the household are an important source of income for recipients and are more common when the economy is weak. Second, although much attention has focused on cash transfers, shared living arrangements provide an alternative means of resource sharing that is quite common among the low-income population; coresidency thus has the potential to be a significant source of support for the poor. Third, the importance of private cash transfers and income from unrelated household members rose beyond that predicted by macroeconomic and demographic changes, suggesting that factors such as changes in public programs (e.g., TANF and the EITC) could also be important. 
Overall, our analysis, like those on which it builds, is limited by the available data. In section 4, we discuss these limitations and offer suggestions for future research, as well as discuss the implications of our findings for public policy.

\section{A synthesis of the related literature}

The recent literature on the well-being of the low-income population has focused on the importance of labor market opportunities and public transfer programs. However, both the robustness of the labor market faced by less-skilled workers and the regulations governing the receipt of public assistance are beyond the control of these individuals. When faced with a reduction in income, an individual may look for assistance from private sources, such as family and friends. Despite the potential importance of private transfers, relatively little research has focused on such assistance. In this section, we draw on a diverse set of literatures to consider the potential importance of private transfers and to lay the ground work for our empirical analyses.

We take a broad view of private transfers, including both cash and non-cash transfers and shared living arrangements. Measurement of these transfers is not always straightforward. For example, imbedded in the value of shared living arrangements is the direct transfer of such tangible items as food, shelter, and household goods, as well as less readily measurable assistance implicit in the returns to scale in household production. ${ }^{2}$ We will use the term "transfers" to refer to direct assistance provided through cash or non-cash transfers or through shared residence, and reserve the more general concept of "resource sharing" to indicate both these direct transfers and the indirect gains obtained through coresidence. In many cases, we do not observe how resources are actually shared among coresident individuals, but rather, we only observe the income of each individual. When discussing the phenomenon of how coresident

\footnotetext{
${ }^{2}$ For example, the fixed cost of telephone service is the same regardless of how many individuals share the apartment
} 
individuals might combine their incomes, we use the term "income pooling." We note also that the focus of this paper is on voluntary resource sharing. We refer the reader to the chapter by Maria Cancian and Meyer (2005) for a discussion of legally mandated transfers such as alimony and child support.

\subsection{Motives for resource sharing}

A family can provide assistance to one of its members out of concern for the well-being of the (potential) recipient (Robert Barro, 1974; Gary Becker, 1974) or as part of a quid pro quo arrangement (B. Douglas Bernheim, Andrei Schleifer and Lawrence Summers, 1985). ${ }^{3}$ These competing explanations, the former an altruistic motivation and the latter based on exchange, have generated a sizable volume of research, with much of it attempting to discern which motive is most consistent with the data. ${ }^{4}$ Despite these efforts, a consensus has yet to be reached, and recent work suggests that each model may play an important role (Audrey Light and Kathleen McGarry, 2004). The existing literature has, however, generally found that transfers are strongly compensatory, with both the probability of a transfer and the amount higher for lower income recipients (Cox, 1987; Joseph Altonji, Fumio Hayashi, Laurence Kotlikoff, 1997; McGarry and Schoeni, 1995, 1997). ${ }^{5}$ Furthermore, the probability of making a transfer and the amount transferred are positively related to the donor's income. These findings suggest that we would likely observe changes in the pattern of resource sharing in response to changes in the income of either party and to changes in the economic environment more generally.

\footnotetext{
${ }^{3}$ Although we are equally interested in sharing among related and unrelated persons and will examine both in our empirical analysis, we follow the existing literature and couch our conceptual discussion in terms of sharing among extended family members.

${ }^{4}$ See Donald Cox (1987) for a clear description of these alternative models of altruism and exchange and a formal test of the validity of the altruism model.

${ }^{5}$ This result is consistent with an altruistic model wherein the donor is seeking to increase the consumption of a less well-off recipient but is also consistent with an exchange regime in which the transfer represents payment for a service, behavior, or previous assistance provided by the recipient.
} 
When family or friends provide assistance in response to declines in the income of the recipient, they could be providing a form of insurance to each other, akin to that provided by formal private insurance markets or by publicly provided social insurance. This notion has been developed in several papers. For example, Kolikoff and Avia Spivak (1981) present a model in which families provide insurance (annuities) for their elderly members to protect against the possibility of "living too long" and exhausting their assets. Similarly Cox (1990) and Cox and Tullio Jappelli (1990) model the potential for familial transfers to alleviate liquidity constraints. Social insurance programs such as unemployment insurance, Social Security, and Workers' Compensation can provide substantial protection against negative shocks to income (for example, Jonathan Gruber, 1997; Susan Dynarski and Gruber, 1997). However, because these programs typically require some previous attachment to the labor force, many of the lowest income individuals may not qualify for benefits. For this population, then, families could play a particularly important role. ${ }^{6}$

\subsection{Modes and magnitudes of resource sharing}

Although economists often focus on cash transfers, resource sharing can occur through other modes like the transfer of goods, time help, or a reduction in expenses through shared living arrangements. The optimal choice of mode is determined by the characteristics of the donor and recipient, such as their financial resources, preferences, and the opportunity cost of their time. For example, a retired parent facing a low opportunity cost of her time may choose to assist her daughter by providing childcare to a grandchild, whereas a fully employed parent might choose to make cash transfers to pay for childcare. These sorts of trade-offs between time and financial

\footnotetext{
${ }^{6}$ The notion of families or communities providing insurance against consumption shortfalls has been emphasized in the context of developing countries where formal insurance markets are less prevalent. Robert Townsend (1995) provides a good discussion of some of the relevant literature.
} 
assistance have been documented in several empirical studies (Kenneth Couch et al., 1999). Despite the potential for transfers of various types to substitute for one another, research has tended to focus on each mode in isolation. ${ }^{7}$

Studies examining cash transfers have found that they are relatively common (Altonji, Hayashi, Kotlikoff, 1997, 2000; McGarry and Schoeni, 1995, 1997). These studies estimate that approximately 20-30 percent of parents make inter vivos transfers to their adult children, with positive transfer amounts averaging from $\$ 2000$ - \$3000 a year. In addition, substantial amounts are transferred as bequests (for example, William Gale and John Karl Scholz, 1994).

Ethnographic evidence also points to the importance of private transfers. In a compelling descriptive study of the resources of low-income households, Katherine Edin and Laura Lein (1997) report that approximately 80 percent of single mothers received transfers from private sources and these transfers accounted for 20 percent of household resources (pp. 150-151). They also find that 25 percent report "doubling-up" with friends or relatives in order to reduce living expenses (pp. 54, 115). However, because their data are not based on a randomly selected sample from a well-defined population, it is not possible to generalize their findings to a population beyond their respondents, nor do they analyze how resource sharing responds to changes in the economic and policy environment.

Of the studies that have attempted to measure non-cash transfers, attention has been primarily limited to the transfer of time. These studies have found that the provision of home health care is the most common type of time transfer, with over one-third of such assistance flowing from adult children to their elderly parents (Department of Health and Human Services, 1998). McGarry and Schoeni (1995) find that, among individuals in their 50s who are providing care to elderly parents, the average amount is over 700 hours a year. At a wage rate of \$18 (MetLife, 2004),

\footnotetext{
${ }^{7}$ Important exceptions to this practice are Mark Rosenzweig and Ken Wolpin (1993, 1994).
} 
these services are comparable to cash transfers of at least $\$ 12,000$ a year. When help with tasks other than personal care items is included in the measure of time help, the fraction providing assistance rises substantially (Altonji, Hayashi and Kotlikoff, 2000). The family also figures prominently in the care of children. In cases in which the mother is employed and not the primary caregiver, nearly 40 percent of the time the primary caregiver is a relative (David Blau and Janet Currie, 2004).

Another potential mode of transfer is the provision of coresidence. This form of assistance is perhaps the most difficult to evaluate. Not only is it difficult to measure accurately the multitude of direct subsidies that are provided through food, shelter, and time help, but monetary values must also be assigned to the returns to scale implicit in such arrangements and the potential costs associated with the loss of privacy. ${ }^{8}$ Empirical analyses of shared living arrangements have again focused largely on the behavior of the elderly (Frances Korbin, 1976; Fred Pampel, 1983; Michael, et al., 1980), with some work examining the behavior of young adults (Leslie Whittington and Elizabeth Peters, 1996).

In many data sets, including the one we use in our empirical analysis, income is collected for each household member but no information is collected on how income is shared. Thomas Deleire and Ariel Kalil (2005) show that expenditures on child-specific consumption items differ markedly between cohabiting and married couples, with cohabitating couples spending less on children. This finding suggests that income is not simply pooled at the household level, but rather that household structure matters. Even more striking, a growing branch of the literature

\footnotetext{
${ }^{8}$ Although we do not attempt to quantify them here, the returns to scale can be considerable. For example, in determining the appropriate poverty thresholds, the U.S. Census Bureau assumes that two individuals need only 28 percent more income than a single individual to obtain the same standard of living. See Constance Citro and Robert Michael (1995) for a detailed discussion of the returns to scale in the poverty measure. These financial gains may be offset, at least in part, by the utility loss associated with less privacy. Magnuson and Smeeding (2005) in a study of low-income new mothers, conclude, "In this case and others we encountered, the decision to live with relatives was determined more $[b y]$ necessity than by choice." (p19).
} 
has focused on income pooling among spouses. Important early work by Duncan Thomas (1990) and Shelly Lundberg, et al. (1997) find that expenditure patterns differ significantly depending on which spouse controls the resources, with mothers devoting a larger share of spending to children. Thus, not only is the assumption of equal sharing likely to be invalid in the case of coresidency, it is unlikely even to hold between spouses. These findings have important implications for our empirical analysis below.

\subsection{Resource sharing and the policy and economic environment}

As we have noted, decisions to share resources within and between households are likely to be influenced by the existing policy and economic environments. In fact, the structure of many government assistance programs explicitly defines the economic unit in which resource sharing is expected to occur. As with much in our society, these assumptions have changed repeatedly over time, reflecting shifts in attitudes regarding public and private roles in meeting economic needs. For example, the former state run Old Age Assistance (OAA) programs often included "relative responsibility" clauses that obligated children to provide financial support to their elderly parents (Elizabeth Epler, 1954). Failure to support needy parents could result in court action and denial of public assistance to the parent. These requirements were abolished in 1974 when the Supplemental Security Income program (SSI) replaced OAA. Similarly, the Aid to Families with Dependent Children (AFDC) initially targeted only unmarried mothers and their children; the presence of any adult male in the household to be sufficient grounds for the denial of benefits, presumably under the assumption that his resources were available to the children. Supreme Court decisions eventually invalidated this assumption (Patterson 2000, p. 173-4), and by the 1980s and 1990s, states generally ignored the resources of non-parents (Moffitt, et al., 
1998). ${ }^{9}$ Under the TANF regulations applicable today, some states have returned to stricter requirements regarding the inclusion of resources from other household members, requiring, for example that a minor mother live with a parent or guardian and including a portion of that parent's income when determining benefits. ${ }^{10}$

Even at a specified time, there is variation across assistance programs in the definition of the economic unit. For example, the Food Stamp Program (FSP) has consistently used a broad definition, including all individuals in a household who purchase or prepare food together, regardless of their relationship (Steven Haider, et al., 2003). In contrast, cash welfare assistance (TANF) generally only includes the income of a child's parent and direct cash assistance from others when computing benefits.

Several studies have examined the extent to which private cash transfers respond to public assistance programs. ${ }^{11}$ In an early empirical study, Robert Lampman and Timothy Smeeding (1983) discuss the potential for government transfers to "crowd-out" or replace private cash assistance and provide suggestive evidence of such a trade-off. More recent studies have confirmed the relationship, finding that private cash transfers decline in response to increased public assistance, although the overall responses are very small (Cox and George Jakubson 1995; Schoeni 1997; Schoeni 2002; Rosenzweig and Wolpin, 1993, 1994).

Similar analyses of the relationships between the policy and economic environments and the choice of living arrangements have been undertaken. With respect to the living arrangements of

\footnotetext{
${ }^{9}$ States differed in their treatment of non-parental income. In terms of benefit calculation, the Supreme Court decision barred the assumption that all income of the non-parent adult benefited the child. However, some states inquired specifically about direct cash transfers to the child and included this amount in the benefit calculation. ${ }^{10}$ See Gretchen Rowe and Victoria Russell (2004) for a more complete description of TANF regulations across states.

${ }^{11}$ Theoretically, the specific relationship depends on the underlying motive for transfers. The predictions are the most clearly defined when altruism is the primary motivation. In this case as the income of a recipient rises, the marginal utility of a dollar transferred to her is reduced, and the marginal utilities of the donor and recipient (appropriately weighted) are equalized with fewer transfers. With an exchange motivation, the exact relationship depends on the relative elasticities for the supply and demand of the exchanged goods.
} 
the elderly, several studies have concluded that the dramatic improvement in the financial situation of older persons evident over much of the last century has led to a sharp decline in the probability of coresidency (Michael, et al., 1980; Saul Schwartz, et al., 1984). Using expansions of Social Security, Old Age Assistance programs and SSI to identify the relationship between income and the living arrangements several studies have subsequently confirmed this relationship and in doing so have demonstrated the important interactions between public and private transfers (Dora Costa, 1999; McGarry and Schoeni, 2000; Gary Englehardt, et al., 2002). Studies of the living arrangement choices of younger populations have demonstrated that they too respond to the structure of cash assistance programs (Rosenzweig and Wolpin 1993, 1994; Mariane Bitler, et al., 2004).

In comparison to even this somewhat limited body of research assessing the interaction between public and private transfers, the relationship between macroeconomic conditions and private transfers has received relatively little attention. Many of the general principles, though, should be the same. To the extent that an improving economy leads to an improvement in the economic status of recipients, we would expect fewer transfers. However, because broad-based economic changes could affect the resources of the donor as well as the recipient, the supply and demand for transfers will change and the net effect may be ambiguous.

\section{Recent trends in incoming sharing}

The recent literature has tended to focus either on transfers from outside the household, referred to as inter-household transfers, or on income pooling within the household, referred to as intra-household transfers. In our empirical work, we examine the relevance of both modes of resource sharing and focus on how these patterns have changed in response to changes in the macroeconomic environment. 


\subsection{Data and definitions}

Our data are drawn from the Current Population Surveys (CPS) for the years 1980 to 2004. We use the March supplements for each year, at which time information is obtained about income in the preceding year. We will thus refer to our data as pertaining to the years 1979 through 2003. The CPS provides detailed information on income components and household living arrangements for a large nationally representative sample. With these data we can identify both cash transfers from outside the household and the potential for income pooling within the household. A detailed household roster allows us to distinguish various types of living arrangements, including whether the other individuals in the household are relatives, nonrelatives, or, in the later years of our data, cohabiting partners. ${ }^{12}$

Our definitions of income sharing are straightforward. For inter-household income sharing, we us the CPS question that specifically asks about "regular financial assistance from friends or relatives not living in this household." This question necessarily limits our focus to cash transfers, although in-kind transfers such as help with child care are likely to be important. In addition, the phrase "regular financial assistance" presumably further limits the type of income transfers that will be reported. Respondents must use their judgment regarding what qualifies as "regular", and transfers that are made to offset a temporary income short-falls may be excluded. Such concerns are corroborated by past research that suggests the CPS-type question dramatically underestimates the amount of private transfers actually received. ${ }^{13}$

\footnotetext{
${ }^{12}$ Information about cohabitating partners is collected from 1994 through the end of our sample period. Although nuclear family relationships are clearly delineated for everyone in the CPS, non-nuclear relatives and cohabiting partners are only identified for the household "reference person", where the reference person is defined to be the person who "owns or rents" the unit (Current Population Survey, 2002).

${ }^{13}$ In 1988, the Panel Study of Income Dynamics (PSID) included a question about private transfers that is fairly similar to the CPS question and an alternatively worded question that asks about transfers more fully. McGarry and Schoeni (1995) show that the alternatively wording increased the prevalence of reported transfers from 4.9 to 20 percent for the same respondents. This result suggests that inter-household transfers in the CPS may be substantially more common than our data indicate.
} 
With regard to intra-household income sharing, the detailed information on the components of income contained in the CPS allows us to measure the income of various household members separately. The ability to define the relationship between household members is central to our analysis, and the definitions we use are largely determined by the structure of the CPS. We define the "nuclear family" as an individual or married couple along with any unmarried and childless children. This nuclear family is part of a potentially larger household, defined to be all individuals occupying an independent housing unit, such as a house or apartment. Other household members are classified as relatives if they are related by blood or marriage to any member of the nuclear family; if not, other household members are as referred to as nonrelatives. Based on these definitions, unmarried, cohabiting partners are not considered to be part of the same nuclear family, but rather in separate, unrelated families.

There are three important considerations that should be noted when examining within household income sharing. First, we do not know the extent to which total household income is indeed shared by household members; we can therefore speak only to the potential for income sharing. Second, along with the potential for pooling cash resources, these shared living arrangements will involve some degree of pooling of non-cash resources, such as time spent engaged in household chores or child care; these we are also unable to measure. Third, there is an implicit gain in resources from the returns to scale in household production, such as the sharing of housing and utility costs and quantity discounts in food. Although these factors are important to understanding the transfers imbedded in coresidency, they are largely ignored in our empirical analysis due to data constraints. 
Our analysis is based on women ages 18 through $54 .{ }^{14}$ For these individuals we examine the incomes of all members of their nuclear family and the incomes of others in the household; income accruing to these "other" household members is further broken down by relationship to our sample person (that from related persons, unrelated persons, and in the years for which it is possible, cohabiting partners). Within these categories we classify income into four sources: earnings, means-tested public transfers, private financial transfers, and other income. In order to highlight the patterns of resource sharing for the low-income population, we divide our sample of individuals into three groups based on schooling level: less than high school, a high school degree, and schooling beyond high school. Our discussion focuses primarily on the less than high school group with the more schooled used for comparisons. We apply sample weights throughout our analysis. ${ }^{15}$

\subsection{Income sharing in 2003}

In the top panel of Table 1, we examine the sources of income for our sample of women. Unsurprisingly, we find extremely large differences in mean nuclear family income by schooling level, as well as differences in the components of income. Nuclear family income for lowschooled women averages $\$ 35,248$, while those in our highest education group report an average nuclear family income of $\$ 77,756$. In terms of the source of this income, labor earnings are a less important component for the less-skilled women than for the more-skilled women while income from means-tested transfer programs is obviously more important. The mean fraction of nuclear family income due to earnings is 78.6 percent for the less-educated women, compared to

\footnotetext{
14 The patterns we report here for women are fairly similar to those observed for men. Due to space constraints we do not report the results for men.

${ }^{15}$ We make two adjustments to these income data. First, we recode negative earnings and negative income to be zero, viewing a loss in these dimensions as a reduction in wealth. Second, we drop from the analysis all households that report zero total income. The results are not sensitive to these decisions.
} 
85.1 percent for women with a high school diploma and 87.4 percent for women with more than a high school education. In contrast, means-tested transfers account for 8.2,3.0 and 1.0 percent of income, respectively.

From the results in the table, private financial transfers are fairly unimportant, comprising on average less than 1 percent of nuclear family income for all educational groups. However, as discussed in Section 3.1, previous studies have concluded that CPS-type questions dramatically underestimate the amount of private transfers actually received. Although we cannot demonstrate it with these data, we expect that private transfers are substantially more important than they appear to be based on this evidence.

The top panel of Table 1 also presents information on the source of total household income for women in our sample. Unsurprisingly, total household income increases with schooling level ranging from $\$ 42,089$ for the least-educated group to $\$ 83,900$ for the most-educated group. However, the fraction of total income attributable to household members outside of the nuclear family is much more important for the less schooled group. For example, among women without a high school diploma, 85 percent of household income accrues to the nuclear family, 6 percent to related household members, and 5 percent to both cohabiting partners and unrelated individuals. For women with more than a high school diploma, the figures are 92 percent to the nuclear family, 2 percent to related household members, and 3 percent to both cohabitors and unrelated individuals. These results suggest that the least-educated women could be relying more on resources stemming from shared living arrangements than are women with more education. Moreover, among the least-educated, transfers arising from shared residence are potentially much more important than transfers from outside the household. Rosenzweig and Wolpin (1994) draw a similar conclusion using NLSY data. 
Although our focus is on all women, we present a similar set of tabulations for single women with a child under eighteen years old in her nuclear family in the lower panel of Table 1 . The same general patterns emerge: nuclear family income and household income increases with education, the relative importance of different income sources are comparable, and the scope for resource sharing from within the household appears to be much greater than the measured private financial transfers reported by a nuclear family. Perhaps the most notable difference between the two panels is that, for less-educated single mothers, the role of related family income in the household is greater than for the general population of less-educated women. For example, related family income comprises 6 percent of household income for all less-educated women, but 13 percent of household income for less-educated single mothers. However, given the similarity in overall patterns, we focus the rest of our analysis on all women.

In Table 2 we focus in more detail on the importance of resource sharing by examining the distributions of these private financial transfers and non-nuclear family income more generally. The table also highlights some of the more interesting differences in demographic characteristics for the recipients and non-recipients of each form of transfer (or potential transfer). Despite the probable under-reporting of the receipt of private cash transfers, columns 1 through 3 demonstrate that when the private transfers are reported, the amounts are large. The mean amount of private transfers for the least schooled is $\$ 6,574$ and one-quarter of the recipients reported transfers over $\$ 7,900$. Because the mean nuclear family income among women in the lowest education group is just $\$ 24,683$, the average cash transfer was nearly one-third of average income. Average transfer amounts are similarly large for the other education groups, with the women in the high school diploma group receiving an average of $\$ 5,182$ and women with more than a high school diploma receiving $\$ 7,621$. However, because nuclear family income is 
substantially higher for these more highly educated women, cash transfers are less important relative to total income.

In comparing those who receive cash transfers with those who do not among the leasteducated women, transfer recipients have lower nuclear family incomes on average than nonrecipients and are less likely to be married, have children, or to be in school. The patterns are similar for the two other educational groups, with the notable exception of the relationship between transfer receipt and school attendance. In each of the more highly educated groups, transfer recipients are substantially more likely to be attending school than their non-transfer counterparts. This difference in school enrollment suggests that the transfers reported in the CPS for those with a high school diploma could represent familial financial assistance in financing a college education.

In columns 4 through 6 of Table 2, we similarly examine non-nuclear family income. The probability of having non-nuclear family income is much higher than that for private financial transfers, ranging from 24 percent for women in the lowest educational group to 15 percent for women in the highest educational group. Moreover, conditional on having some non-nuclear family income, the amount of such income is actually larger than mean nuclear family income, a result holds for all educational groups. The existence of non-nuclear family income is concentrated among those who are relatively young, less likely to be married, and less likely to have children. Overall, the recipient/non-recipient comparisons for non-nuclear family income are similar to those for private financial transfers, consistent with the notion that private financial transfers and coresidency are different modes of the same economic process of income sharing. 


\subsection{Trends in income sharing}

In Figure 1, we show the trends from 1979 to 2003 in the importance of various components of household income for each of our schooling categories. The height of each line depicts the sample average of the fraction of total household income coming from each of three underlying components: nuclear family income, related family income, and unrelated/cohabiting family income. The first panel demonstrates a clear decline over time in the relative importance of nuclear family income. This decline is particularly dramatic for the less educated women, falling from approximately 94 percent of total household income in 1979 to 85 percent in 2003. As the next two panels demonstrate, this decline was offset by an increase in the fraction of income coming from unrelated/cohabiting individuals (a 7 percentage point increase) and a somewhat smaller increase in the fraction of household income from related family members (a 4 percentage point increase).

There are two potential sources for the substantial decline in the fraction of total income attributable to individuals in the nuclear family: changes in the composition of household living arrangements or changes in the importance of nuclear family income within living arrangement type. As an example of the first source, suppose disadvantaged women begin to coreside with other individuals (who are not their spouses). To the extent that these other individuals have income, then these women will experience a decline in the amount of total income attributable to the nuclear family. Alternatively, even for households for which the composition remains unchanged, the income received by the members of the nuclear family could decline relative to that received by other household members.

In figure 2 we decompose the total change in the fraction of household income coming from the nuclear family into the portion attributable to each of these sources and we do so separately 
for each of our three schooling groups. ${ }^{16}$ We consider four mutually exclusive and exhaustive living arrangement groups: (1) married women, (2) unmarried women who live with only nuclear family members, (3) unmarried women who live with at least some related family members but not any unrelated individuals, and (4) unmarried women who live with any unrelated individuals, regardless of whether there are other relatives in the household. The top panel presents the results for the years 1979-2003. The first bar in each set shows the total decline and the next two bars illustrate the portion due to a change in living arrangements and the portion due to a change in income shares within living arrangement. The height of each bar depicts the percent decline. For those in the less than high school category, the total change in the fraction of household income attributable to nuclear family income is a reduction of 9.5 percentage points. Of this decline, about three-quarters $(-7.0 /-9.5)$ is attributable to changes in living arrangements and the remaining one-quarter is attributable to changes in income fractions within living arrangement types. For the more schooled groups, the decline in nuclear family income is less (6.9 percentage points for women with a high school diploma and 2.8 percentage points for women with more than a high school diploma), but the relative importance of the two sources of change are similar.

\footnotetext{
${ }^{16}$ The decomposition is implemented as follows: Let $\theta_{t}$ be the population ratio of nuclear family income to household income at time t. Let $\theta_{t}^{j}$ be the equivalent ratio for each subgroup $j$ at time $t$, and let $\pi_{t}^{j}$ be the proportion of the population in each subgroup. For the simple case with just two subgroups, $a$ and $b, \theta_{t}$ can be written as a weighted average of the income ratio for each subgroup, i.e. $\theta_{t}=\pi_{t}^{a} \theta_{t}^{a}+\pi_{t}^{b} \theta_{t}^{b}$. Then the change in the relative importance of nuclear family income between time $t$ and $s$ can be expressed as

$$
\theta_{t}-\theta_{s}=\left(\pi_{t}^{a}-\pi_{s}^{a}\right) \theta_{s}^{a}+\left(\pi_{t}^{b}-\pi_{s}^{b}\right) \theta_{s}^{b}+\left(\theta_{t}^{a}-\theta_{s}^{a}\right) \pi_{t}^{a}+\left(\theta_{t}^{b}-\theta_{s}^{b}\right) \pi_{t}^{b}
$$

where the first two terms reflect the effect of shifts in the proportion of the population in groups a and $b$, holding relative income constant at the initial period $(s)$ level, and the second two terms reflect the change due to changes in the relative importance of nuclear family income, holding the proportion of the population in each group constant at the final period $(t)$ level.
} 
Using this decomposition technique, we can also examine which types of living arrangements rose in prominence and which declined. (This decomposition is illustrated in appendix table A1). We find that the 75 percent of the decline in the importance of nuclear family income that was due to changing living arrangements arose primarily to a reduction in the proportion of women living in the married household and an increase in the proportion in each of our three unmarried groups. Among these unmarried groups, the increase in women living with unrelated individuals (possibly cohabiting partners) was twice as important as the increases in the two other unmarried groups.

These results demonstrate an important increase in the number of women living with unrelated individuals. One potential explanation for this increase is a movement from marriage to cohabitation because, as we noted earlier, spouses are defined to be part of the same nuclear family while cohabiting partners are not. Such a movement would thus shift income from the nuclear family to an unrelated family member. To examine this possibility, we repeat our analysis for the period 1994-2003, the years in which the CPS distinguishes between cohabiting partners from other unrelated individuals. These results are presented in the lower panel of Figure 2. The overall change in the importance of nuclear family income for the least schooled category over this shorter time period is a decline of 2.4 percent, somewhat smaller than would be expected if the change over the longer time period were distributed evenly. Furthermore, the source of the change is divided about equally between changes in living arrangements and changes in the distribution of income within household types (-1.1 and -1.2 percent). When we once again disaggregate these results further to examine the role of specific types of living arrangements (not shown), we find that all of the decline due to changing living arrangements is attributable to increased cohabitation. 
We now turn to a detailed examination of the components of nuclear family income. We examine four nuclear family income sources: (1) earnings, (2) means tested transfers, (3) private financial transfers (including child support, and alimony), and (4) other income (e.g., asset income, retirement benefits, workers' compensation, and unemployment insurance). Figure 3 graphs the respective fractions of household income due to these components over our sample period.

For women in the lowest educational category, there was a fairly consistent decline in the importance of earnings throughout the 1980s and early 1990s. However, beginning in 1994, there was a sharp reversal of this trend with the portion of family income coming from earnings increasing substantially. This reversal is likely related to the strong economic growth during this period and changes in welfare policy (Schoeni and Blank, 2000; Jacob Klerman and Haider, 2004). The pattern for means-tested public transfers mirrors that for earnings, increasing during the 1980 s and early 1990 s and then falling dramatically.

Although it is difficult to discern in the figure, there is a notable increase in income coming from private financial transfers, child support or alimony, particularly towards the end of this period. ${ }^{17}$ The change is small in an absolute sense, increasing from 2 to 3 percentage points of family income, but large in percentage terms, increasing by 50 percent. This trend towards private transfers could be a response to the decline in public support, as well as to the increased efforts to establish paternity and collect child support (Cancian and Meyer, 2005). Also of interest is the relatively high and consistent level of related family income, remaining fixed at approximately 10 percent throughout the period for the least-educated women.

\footnotetext{
${ }^{17}$ We combine these sources because they are not separately identified until 1987.
} 


\subsection{Assessing macroeconomic effects}

In order to assess the relationship between the economy and the relative importance of the various sources of income net of other household characteristics, we turn to a regression analysis. For this exercise we divide household income into six categories, four of which pertain to the income of the nuclear family (earnings, means-tested public transfers, private transfers, and other income) and two of which pertain to income accruing to non-nuclear members (related family income and unrelated/cohabiting income). We then construct six different dependent variables $Y_{i t}$ to be the percent of total household income due to each of these sources and regress these dependent variables on a measure of macroeconomic performance and other standard controls. ${ }^{18}$ Specifically, we estimate the regression equation

$$
Y_{i t}=\beta_{0}+\beta_{1} U_{i t}+\beta_{2} X_{i t}+\alpha_{s}+\gamma_{t}+\varepsilon_{i t} .
$$

We use annual state unemployment rates $U_{i t}$ as our proxy for the macroeconomic conditions. As other controls $X_{i t}$, we include our three schooling levels, race/ethnicity, age, marital status, whether the woman is enrolled in school, and the presence of children in the nuclear family. State fixed effects $\alpha_{s}$ are included to control for persistent differences across states in policies and the economic environment. We use year fixed effects $\gamma_{t}$ to capture other nationwide changes over time, such as changes in public assistance programs, the EITC, and social norms. We use data from 1987 through 2003 yielding approximately three-quarters of a million observations. We present only the results for our key coefficient $U_{i t}$ in Table 3; appendix table A2 provides complete regression results.

Unsurprisingly, we find that higher unemployment rates are associated with a reduced percentage of household income due to nuclear family earnings and an increased fraction of

\footnotetext{
${ }^{18}$ Because the dependent variables sum to 100 across income sources for each individual, the coefficients on any particular regressor must sum to zero across income sources. The individual coefficients should be interpreted as the relative cyclicality of each of the underlying sources.
} 
means-tested public transfers. These effects, although statistically strong, are not economically large. An increase in the unemployment rate of 1 percentage point is associated with a decline of 0.5 percentage points in the fraction of income coming from labor earnings of nuclear family members. This is equivalent to a decline of just 0.6 percent $(0.522 / 77.99)$. The increase in the probability of means tested transfers associated with a 1 percentage point increase in the unemployment rate is even smaller in percentage point terms $(0.2)$, but because such transfers are less common than labor earnings, the percentage effects are large, corresponding to a 5.8 percent increase in the fraction of income due to means-tested public transfers $(0.186$ / 3.22). Private transfers also increase significantly with the unemployment rate by a similar 5.7 percent (an increase of 0.024 percentage points). Thus, even though private transfers are relatively rare, they potentially play an important role in smoothing the consumption of low income families over the business cycle. However, we find no significant relationship between the unemployment rate and the income from either category of non-nuclear family members.

Our regression methodology also allows us examine yearly trends in the importance of income sources, net of the business cycle and other factors that are controlled for in the regressions. These trends are simply the coefficients on the dummy variables denoting each year of our sample. In Figure 4 we plot the values of these coefficients for each of the six regressions. Many of the same patterns we have already identified are apparent. Perhaps most importantly, there is a strong secular increase in earnings from unrelated and cohabiting individuals, reaching almost 3 percentage points by the end of our sample period. There is also a steady increase in the fraction of household income due to related family members. Finally, the decline and then increase in the importance of nuclear family earnings, with an opposite pattern for means-tested transfers, is also apparent in these estimated effects. 


\subsection{Poverty rates and income sharing}

The results presented thus far indicate that private cash transfers and transfers through shared living arrangements can be important sources of support for the low-income population. In this section we address the potential for these transfers to mitigate economic hardship. To do so, we examine the effect of various transfers and income pooling arrangements on poverty rates. The basis for our analysis is the official poverty measure defined by the U.S. Census Bureau, but we explore alternative definitions of income and the relevant economic unit. ${ }^{19}$

In Table 5 we tabulate the poverty rate for seven different definitions of the appropriate economic unit and income measure. In the first row of table 5, the economic unit is defined to be the nuclear family and income to be total nuclear family income, exclusive of all means-tested transfers and all private cash transfers. For the lowest schooled in our sample, the poverty rate based on this definition is 35.6 percent. The next row adds public transfers to the definition of income but continues to exclude private cash transfers. The poverty rate for the least-educated group falls to 33.9 percent. Adding private transfers as well (row 3) has little effect on poverty, reducing the rate to 33.8 percent. In the next row we expand the economic unit to include all related family members in the household and increase income and the needs standard accordingly. This poverty measure, which corresponds to the official Census definition, is 31.4 percent. This decline in the poverty rate indicates that related persons bring more than enough income to the household to cover their needs (as defined by the increment in the poverty threshold).

\footnotetext{
${ }^{19}$ The Census definition of poverty is based on a comparison of the income of the economic unit (defined as all related members of a household) to an income threshold specific to the size of the unit. This measure provides a convenient metric for judging well-being that is widely cited and easily calculated for varying sized economic units and income measures. However, it is not without its critics. See Citro and Michael (1995) for a discussion of its weakness and some suggested modifications.
} 
In row 5 , we define the economic unit to be the nuclear family with just cohabiting partners. It might be that such an economic unit better corresponds to actual income pooling arrangements than does the official poverty measure. Although the poverty rate falls substantially compared to the poverty rate based on the nuclear family alone, it is quite similar to that calculated for the related family in row 4 (the official poverty measure). When we further expand the economic unit to include both related family members and cohabiting partners (row 6), the poverty rate declines even further to 28.6 percent. The final row (row 7) incorporates all persons in the household and the poverty rate drops to 26.4 percent for the least schooled and 5.9 percent for those with the most schooling. Thus, the "choice" to live with others has the potential to improve economic well-being substantially. In total, the poverty rate declines by over 20 percent when the relevant unit is expanded from the nuclear family with all public and private transfers included in income (row 3) to the extended household.

We note, however, that these broader definitions assume that household income is shared the same way among members of the economic unit, regardless of their relationships. Such an assumption is almost certainly not true.

\section{Conclusions and discussion}

Individuals have many dimensions over which they can adjust their behavior in response to economic change. They may increase or decrease employment levels, retrain for a new job, alter their reliance on public assistance programs, or give or receive private support from family and friends. Despite the central role the family plays in current policy discussions, surprisingly little research has examined the role of the family in providing protection against negative economic shocks. To begin to fill this void, we provide a synthesis of several related literatures on private 
transfers and then present new empirical evidence regarding the importance of these transfers and how they vary with the economic and policy environments.

The theoretical literature contains several well-developed models of resource sharing between and within households that provide important insights into possible motives. Moreover, the existing empirical literature demonstrates clearly that individuals make substantial transfers and numerous modes of resource sharing are employed. Furthermore, recent work suggests that the probability and amount of cash transfers depend on the resources of both the potential donors and recipients and on the availability of public assistance programs. However, few studies have examined simultaneously multiple modes of assistance, how transfers vary over time, or how transfers respond to the economic environment more generally. Our empirical work begins to fill these gaps.

We find that transfers provide an important source of support for low-income individuals, with coresidency being particularly important. In addition, our results indicate that, while transfers respond significantly to macroeconomic conditions, there has also been a steady increase in shared living arrangements that is unexplained by macroeconomic and demographic changes. We hypothesize that these changes may be due to changes in attitudes and social norms.

As in past studies, our investigation of cash transfers is limited by the data. Inter-household cash transfers appear to be poorly measured in the CPS and it is thus impossible to assess accurately their true significance. However, we do find that when such transfers are reported, the amounts are large relative to the non-transfer incomes of the recipients. More recent surveys, such as the Health and Retirement Study, employ more detailed questions on transfers than have been asked in the past and will provide the opportunity to re-examine this issue in the future. We note also that the phenomenon of income sharing within households is also poorly understood. 
Although economists have developed elegant household bargaining models that predict that the income of household members is unlikely to be pooled completely, an understanding of exactly how such income is shared awaits additional empirical analyses. We do, however, emphasize that the potential for improvement in financial status from income pooling is large.

Finally, one of the more important avenues for additional research is an examination of the choice of living arrangements. Decisions about coresidence depend on the living arrangement options available to an individual, the availability of other forms of public and private support, household production processes, and the relative value of privacy. Because of the degree of complication involved in the decision making process, a rigorous investigation of co-residency requires sophisticated modeling and extremely detailed data. Although difficult, an understanding of the decision to live with others and the transfers embedded in such arrangements are crucial for an understanding of the resources available to the low income population.

Despite the limitations of our study, our results suggest at least two important lessons for public policy. First, when interpreting the effects of economic or policy changes, the potential for changes in private support must be considered. For example, studies which find only small effects of welfare reform on income may miss the importance of income provided by family and friends and thus the burdens imposed on non-welfare recipients. Second, the functioning of public assistance programs and poverty measurement depend critically on the definition of the economic unit. Any definition makes implicit assumptions about how resources are shared among family and household members, yet there exists relatively little empirical evidence to justify the choice of one definition over the other. This again highlights the importance of a 
additional research on private transfers and the responsiveness of these transfers to changes in

public assistance programs and in the economy.

\section{References}

Altonji, Joseph, Fumio Hayashi, and Laurence Kotlikoff, 2000. "The Effects of Earnings and Wealth on Time and Money Transfers between Parents and Children," in A. Masson and G. Tapinos, eds. Sharing the Wealth: Demographic Change and Ecnomic Transfers between Generations, Oxford University Press: 306-357.

Altonji, Joseph, Fumio Hayashi, and Laurence Kotlikoff, 1997. "Parental Altruism and Inter Vivos Transfers: Theory and Evidence," The Journal of Political Economy, 105(6):1121-1166.

Autor, David, Lawrence Katz, and Melissa Kearney, 2004. "Trends in U.S. Wage Inequality: A Re-Assessment of the Revisionists," Harvard University manuscript.

Barro, Robert, 1974. “Are Government Bonds Net Wealth?” Journal of Political Economy, 82(6): 1095-1117.

Becker, Gary, 1974. "A Theory of Social Interactions," The Journal of Political Economy 82(6):1063-1093.

Bernheim, B. Douglas, Andrei Shleifer and Lawrence Summers, 1985. "The Strategic Bequest Motive," The Journal of Political Economy, 93(6):1045-1076.

Bitler, Mariane, Jonah Gelbach, and Hilary Hoynes, 2004. "Welfare Reform and Children's Living Arrangements," University of Maryland manuscript.

Blank, Rebecca, 2002. "Evaluating Welfare Reform in the United States," Journal of Economic Literature, 40(4):1105-66.

Blank, Rebecca and Robert Schoeni, 2003. "Changes in the Distribution of Children's Family Income Over the 1990s," American Economic Review, Papers and Proceedings, 93(2):304-308.

Blau, David and Janet Currie, 2004. "Preschool, Day Care, and Afterschool Care: Who's Minding the Kids?” NBER Working paper 10670.

Cancian, Maria and Dan Meyer, 2005. "How are Child Support Payments Affected by the Economic Cycle?" in Shifting Resources: The Next Generation of Research on Economic Changes, Public Policy Changes and Poverty, eds., Rebecca Blank, Sheldon Danziger and Robert Schoeni.

Citro, Constance F., and Robert T. Michael, 1995. Measuring Poverty: A New Approach. National Research Council, National Academy Press: Washington, DC. 
Costa, Dora, 1999. “A Home of Her Own,” The Journal of Public Economics,” 72(1):39-59.

Couch, Kenneth, Mary Daly and Douglas Wolf, 1999. "Time? Money? Both? The Allocation of Resources to Older Parents," Demography, 36(2):219-232.

Cox, Donald, 1990. "Intergenerational Transfers and Liquidity Constraints," The Quarterly Journal of Economics, 105(1):187-217.

Cox, Donald, 1987. "Motives for Private Income Transfers," The Journal of Political Economy, 95(3):508-546.

Cox, Donald and George Jakubson. 1995. "The Connection Between Public Transfes and Private Interfamily Transfers," Journal of Public Economics, 57(1):129-167.

Cox, Donald and Tullio Jappelli. 1990. "Credit Rationing and Private Transfers: Evidence from Survey Data," The Review of Economics and Statistics, 72(3): 445-454.

Current Population Survey. 2002. "Current Population Survey: Design and Methodology." Burea u of Labor Statistics Technical Paper 63RV.

Danziger, Sheldon, Colleen Heflin, Mary Corcoran, Elizabeth Oltmans, and Hui-Chen Wang, 2002. "Does It Pay to Move from Welfare to Work?" Journal of Policy Analysis and Management, 21(Fall):671-692.

DeLeire, Thomas and Ariel Kalil, 2005. "How Do Cohabiting Couples with Children Spend Their Money?" Journal of Marriage and Family, 67:285-294.

Department of Health and Human Services, 1998. "Informal Caregiving Compassion in Action," Washington, D.C. DHHS: Office of the Assistant Secretary for Planning and Evaluation.

Dynarski, Susan and Jonathan Gruber, 1997. "Can Families Smooth Variable Earnings?" Brookings Papers on Economic Activity, 1997(1):229-303.

Edin, Kathryn and Laura Lein, 1997. Making Ends Meet, New York, Russell Sage Foundation.

Engelhardt, Gary, Jonathan Gruber, and Cynthia Perry, 2002 "Social Security and Elderly Living Arrangements," NBER working paper number 8911.

Epler, Elizabeth 1954. “Old-Age Assistance: Plan Provisions on Children's Responsibility for Parents," Social Security Bulletin, April:3-12.

Gale, William and John Karl Scholz, 1994. "Intergenerational Transfers and the Accumulation of Wealth," The Journal of Economic Perspectives, 8 (4) : 145-160. 
Gruber, Jonathan, 1997. "The Consumption Smoothing Benefits of Unemployment Insurance," The American Economic Review, 87(1):192-205.

Haider, Steven J., Alison Jacknowitz, and Robert F. Schoeni. 2003. "Food Stamps and the Elderly: Why Is Participation so Low?” Journal of Human Resources, 38(S):1080-1111.

Klerman, Jacob, and Steven J. Haider. 2004. "A Stock-Flow Analysis of the Welfare Caseload." Journal of Human Resources, 39(4):865-886.

Korbin, Frances, 1976. "The Fall in Household Size and the Rise of the Primary Individual," Demography, 13:127-138.

Kotlikoff, Laurence and Avia Spivak, 1981. "The Family as an Incomplete Annuities Market," The Journal of Political Economy, 89(2):372-391.

Lampman, Robert and Timothy Smeeding, 1983. "Interfamily Transfers as Alternative to Government Transfers to Persons," Review of Income and Wealth, 29:45-66.

Light, Audrey and Kathleen McGarry, 2004. "Why Parents Play Favorites: Explanations for Unequal Bequests," The American Economic Review, 39(4):624-648.

Lundberg, Shelly and Robert Pollak, and Terence Wales, 1997. "Do Husbands and Wives Pool Their Resources? Evidence from the United Kingdom Child Benefit." Journal of Human Resources, 32(3):463-480.

Magnuson, Katherine and Timothy Smeeding, 2005. "Earnings, Transfers and Living Arrangements in Low-income Families: Who Pays the Bills?" paper presented at the National Poverty Center conference "Mixed Methods Research on Economic Conditions, Public Policy, and Family and Child Well-being, Ann Arbor, MI.

McGarry, Kathleen and Robert Schoeni, 1995, "Transfer Behavior in the Health and Retirement Study: Measurement and the Redistribution of Resources within the Family," Journal of Human Resources, 30(S):184-226.

McGarry, Kathleen and Robert Schoeni, 1997, "Transfer Behavior Within the Family: Results From the Asset and Health Dynamics Study," The Journals of Gerontology Series B, 52B:82-92.

MetLife Mature Market Institute, 2004. Market Survey of Nursing Home and Home Health Care Costs, Westport, CT : MetLife Mature Market Institute.

Meyer, Bruce and Dan Rosenbaum, 1999. "Welfare, the Earned Income Tax Credit, and the Labor Supply of Single Mothers," NBER working paper 7363.

Michael, Robert, Victor Fuchs and S. Scott, 1980. "Changes in the Propensity to Live Alone: 1950-1976," Demography 17:39-53. 
Moffitt, Robert and Katie Winder, 2005. "Does It Pay to Move From Welfare to Work? A Comment on Danziger, Heflin, Corcoran, Oltmans, and Wang." Journal of Policy Analysis and Management, 24(2):399-409.

Moffitt, Robert, Robert Reville, and Anne Winkler, 1998. "Beyond Single Mothers:

Cohabitation and Marriage in the AFDC Program,” Demography, 35(3):259-278.

Pampel, Fred, 1983. "Changes in the Propensity to Live Alone: Evidence from Consecutive Cross-Sectional Surveys, 1960-1976,” Demography, 20(4):433-448.

Patterson, James T., 2000. America's Struggle against Poverty in the Twentieth Century. Cambridge, MA: Harvard University Press.

Rosenzweig, Mark and Kenneth Wolpin, 1993. "Intergenerational Support and the Life-Cycle Incomes of Young Men and Their Parents: Human Capital Investments, Coresidence, and Intergenerational Financial Transfers," Journal of Labor Economics, 11(1):84-112.

Rosenzweig, Mark and Kenneth Wolpin, 1994. "Parental and Public Transfers to Young Women and Their Children," The American Economic Review, 84 (5):1195-1212.

Rowe, Gretchen and Victoria Russell, 2004. "The Welfare Rules Databook: State Polices as of July 2002,” Urban Institute Discussion Paper 04-06.

Schoeni, Robert, 1997. "Does Aid to Families with Dependent Children Displace Familial Assistance?" University of Michigan manuscript.

Schoeni, Robert, 2002. “Does Unemployment Insurance Displace Familial Assistance?” Public Choice 110(1-2): 99-119.

Schoeni, Robert and Rebecca Blank, 2000. "What Has Welfare Reform Accomplished? Impacts on Welfare Participation, Employment, Income, Poverty, and Family Structure," University of Michigan manuscript.

Schwartz, Saul, Sheldon Danziger, and Eugene Smolensky, 1984. "The Choice of Living Arrangements Among the Aged," in Retirement and Economic Behavior, Henry Aaron and Gary Burtless, eds. Washington, D.C. : Brookings Institute.

Thomas, Duncan, 1990. "Intra-household Resource Allocation: An Inferential Approach." Journal of Human Resources, 25(4):635-664.

Townsend, Robert, 1994. "Risk and Insurance in Village India,” Econometrica, 62(3):539-591.

Townsend, Robert, 1995. "Consumption Insurance: An Evaluation of Risk-Bearing Sustems in Low-Income Economies," The Journal of Economic Perspectives, 9(3):83-102. 
Whittington, Leslie and Elizabeth Peters, 1996. "Economic Incentives for Financial and Residential Independence.” Demography, 33(1):82-97. 
Table 1: Income by Source, Family Unit, and Education, 2003

\begin{tabular}{|c|c|c|c|}
\hline & Less HS & $H S$ & More HS \\
\hline \multicolumn{4}{|l|}{ All women } \\
\hline Observations & 7,007 & 16,926 & 32,821 \\
\hline Mean nuclear family income & 35,248 & 51,034 & 77,756 \\
\hline \multicolumn{4}{|c|}{ Percent of nuclear family income by source ${ }^{\S}$} \\
\hline Earnings & 78.6 & 85.1 & 87.4 \\
\hline Private financial transfers & 0.5 & 0.5 & 0.9 \\
\hline Means-tested transfers ${ }^{\dagger}$ & 8.2 & 3.0 & 1.0 \\
\hline Other ${ }^{\ddagger}$ & 12.7 & 11.4 & 10.7 \\
\hline Mean household income & 42,089 & 57,906 & 83,900 \\
\hline \multicolumn{4}{|c|}{ Percent of household income by source } \\
\hline Nuclear family income & 84.6 & 89.0 & 92.1 \\
\hline Related family income & 5.8 & 3.6 & 1.8 \\
\hline Cohabiting family income & 4.9 & 4.3 & 2.7 \\
\hline Non-related family income & 4.6 & 3.1 & 3.3 \\
\hline \multicolumn{4}{|l|}{ Single mothers } \\
\hline Observations & 1,034 & 1,976 & 2,981 \\
\hline Mean nuclear family income & 31,568 & 32,339 & 54,126 \\
\hline \multicolumn{4}{|c|}{ Percent of nuclear family income by source ${ }^{\S}$} \\
\hline Earnings & 73.1 & 79.0 & 80.4 \\
\hline Private financial transfers & 0.3 & 0.7 & 0.4 \\
\hline Means-tested transfers ${ }^{\dagger}$ & 11.7 & 6.0 & 2.5 \\
\hline Other & 15.0 & 14.3 & 16.6 \\
\hline Mean household income & 41,145 & 46,179 & 64,974 \\
\hline \multicolumn{4}{|c|}{ Percent of household income by source } \\
\hline Nuclear family income & 77.2 & 76.8 & 85.3 \\
\hline Related family income & 13.0 & 12.7 & 9.0 \\
\hline Cohabiting family income & 6.4 & 7.4 & 3.8 \\
\hline Non-related family income & 3.3 & 3.1 & 1.9 \\
\hline
\end{tabular}

$\S$ These tabulations are the mean across families of the fraction of income by source; nuclear families with zero total income are excluded.

${ }^{\dagger}$ Means-tested transfers include income from the Temporary Assistance for Needy Families (TANF) program and the Supplemental Security Income (SSI) program.

${ }^{\ddagger}$ Other income includes transfers from the unemployment insurance, disability insurance, and workers' compensation programs, alimony and child support, asset income, retirement benefits, and other miscellaneous income. 
Table 2: Transfers by Source and Education, 2003

\begin{tabular}{|c|c|c|c|c|c|c|}
\hline & \multicolumn{3}{|c|}{ Private financial transfers } & \multicolumn{3}{|c|}{ Non-nuclear family income } \\
\hline & $\begin{array}{c}\text { Less } H S \\
\text { (1) }\end{array}$ & $\begin{array}{l}H S \\
(2)\end{array}$ & $\begin{array}{c}\text { More } H S \\
\text { (3) }\end{array}$ & $\begin{array}{c}\text { Less } H S \\
\text { (4) }\end{array}$ & $\begin{array}{l}H S \\
(5)\end{array}$ & $\begin{array}{c}\text { More } H S \\
\text { (6) }\end{array}$ \\
\hline Proportion receiving any & 0.011 & 0.013 & 0.022 & 0.236 & 0.190 & 0.146 \\
\hline \multicolumn{7}{|c|}{ Amount of transfers among recipients } \\
\hline Observations & 64 & 196 & 583 & 1,643 & 3,224 & 4,425 \\
\hline $25^{\text {th }}$ percentile & 960 & 900 & 2,000 & 12,156 & 14,400 & 16,014 \\
\hline Median & 2,000 & 2,000 & 4,500 & 21,800 & 26,000 & 30,200 \\
\hline $75^{\text {th }}$ percentile & 7,920 & 5,000 & 9,000 & 37,400 & 45,676 & 51,696 \\
\hline Mean & 6,574 & 5,182 & 7,621 & 28,987 & 36,258 & 42,116 \\
\hline Standard error of mean & 1,388 & 685 & 409 & 707 & 779 & 692 \\
\hline \multicolumn{7}{|l|}{ Characteristics of recipients } \\
\hline Observations & 64 & 196 & 583 & 1,643 & 3,224 & 4,425 \\
\hline Nuclear family income & 24,683 & 26,072 & 31,318 & 17,169 & 26,619 & 37,105 \\
\hline Household income & 26,615 & 30,285 & 41,542 & 46,156 & 62,877 & 79,221 \\
\hline Age & 34.5 & 31.3 & 28.9 & 31.9 & 33.3 & 32.2 \\
\hline Proportion married & 0.200 & 0.266 & 0.212 & 0.232 & 0.193 & 0.139 \\
\hline Proportion with children & 0.493 & 0.460 & 0.280 & 0.486 & 0.420 & 0.284 \\
\hline Proportion in school & 0.105 & 0.126 & 0.379 & 0.095 & 0.047 & 0.173 \\
\hline \multicolumn{7}{|c|}{ Characteristics of non-recipients } \\
\hline Observations & 6,943 & 16,730 & 32,238 & 5,364 & 13,702 & 28,396 \\
\hline Nuclear family income & 35,362 & 51,369 & 78,817 & 40,833 & 56,743 & 84,699 \\
\hline Household income & 42,257 & 58,277 & 84,868 & 40,833 & 56,743 & 84,699 \\
\hline Age & 33.8 & 37.1 & 36.8 & 34.3 & 37.9 & 37.4 \\
\hline Proportion married & 0.472 & 0.571 & 0.580 & 0.542 & 0.654 & 0.646 \\
\hline Proportion with children & 0.624 & 0.539 & 0.508 & 0.664 & 0.566 & 0.541 \\
\hline Proportion in school & 0.126 & 0.039 & 0.094 & 0.135 & 0.038 & 0.087 \\
\hline
\end{tabular}


Table 3: OLS Model for Fraction of Household Income by Source

\begin{tabular}{lcccccc} 
& \multicolumn{3}{c}{ Nuclearfamily income sources } & \multicolumn{2}{c}{$\begin{array}{c}\text { Non-nuclearfamily } \\
\text { income sources }\end{array}$} \\
\cline { 2 - 7 } Regressor & Earnings & $\begin{array}{c}\text { Private } \\
\text { transfers }\end{array}$ & $\begin{array}{c}\text { Means- } \\
\text { tested }\end{array}$ & Other & $\begin{array}{c}\text { Related } \\
\text { indiv. }\end{array}$ & $\begin{array}{c}\text { Unrelated } \\
\text { indiv }\end{array}$ \\
\hline Unemployment rate & -0.522 & 0.024 & 0.186 & 0.320 & 0.009 & -0.017 \\
& $(0.044)^{* *}$ & $(0.008)^{* *}$ & $(0.022)^{* *}$ & $(0.030)^{* *}$ & $(0.020)$ & $(0.027)$ \\
Mean of the dep var & 77.99 & 0.42 & 3.22 & 9.59 & 2.77 & 6.01 \\
R-squared & 0.200 & 0.010 & 0.110 & 0.040 & 0.040 & 0.160 \\
\hline
\end{tabular}

The estimates for these tables are based on equation 1 from the text. The regressions are based on a sample of 736,024 observations. 
Table 4: Percent Poor by Alternative Definitions of Economic Unit and Income, 2003

Less $H S$

(1) Nuclear family, excluding public \& private transfers

(2) Nuclear family, excluding private transfers

(3) Nuclear family

(4) Nuclear + related family (official rate)

(5) Nuclear + cohabitor family

(6) Nuclear + related + cohabitor family

(7) Entire household
35.6

33.9

33.8

31.4

31.0

28.6

26.4
HS

16.6

15.7

15.6

14.1

13.8

12.4

11.3

More HS

8.7

8.4

7.8

7.1

7.0

6.3

5.4 
Figure 1: Components of Total Household Income

Nuclear Family Income

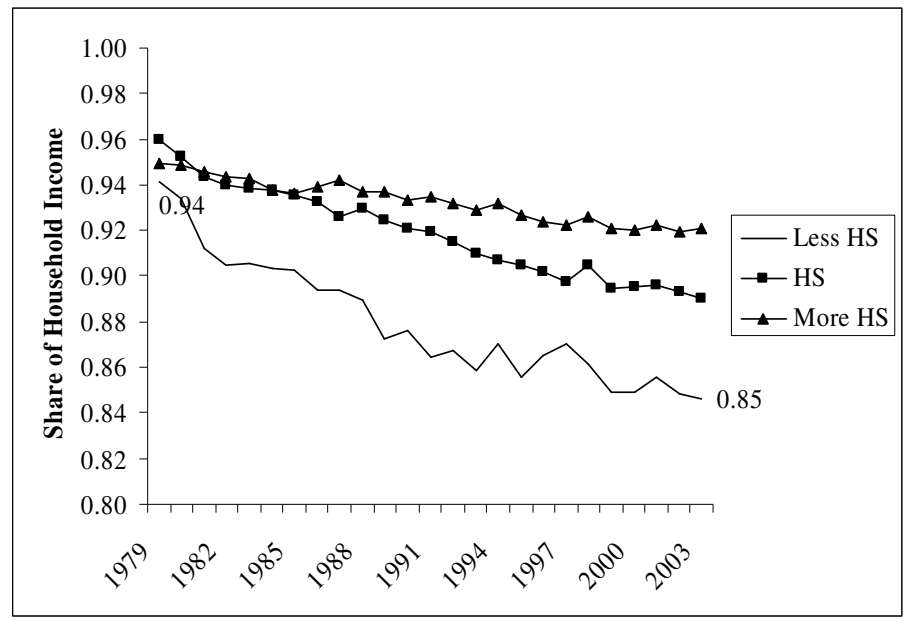

Unrelated/Cohabitor Family Income

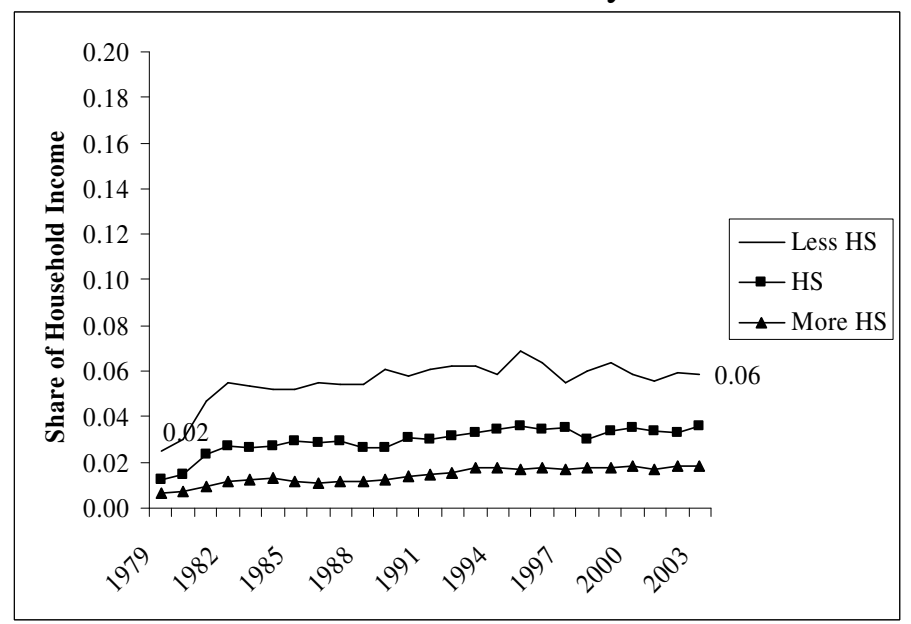

Related Family Income

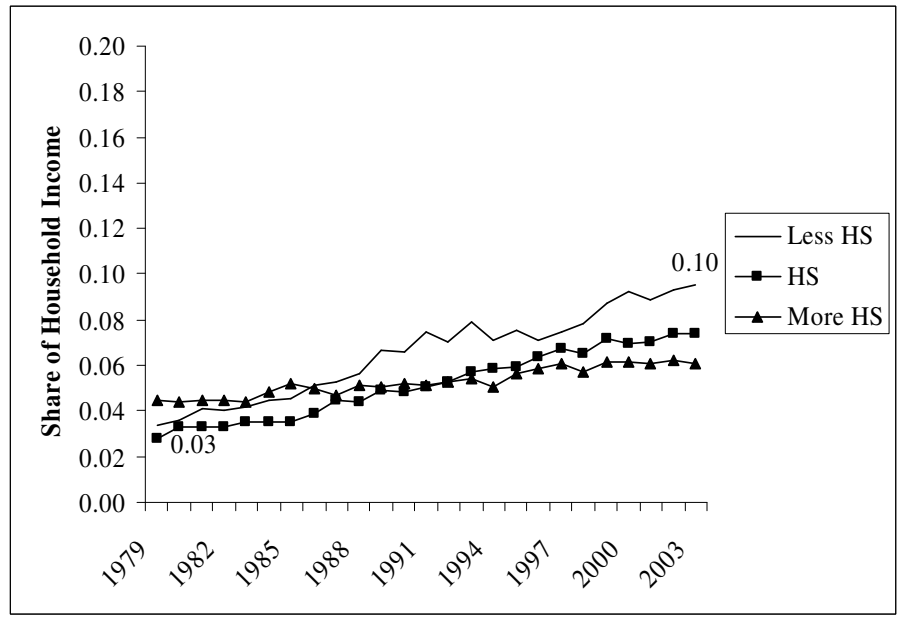

p. 36 
Figure 2: Decomposition of Decline in Nuclear Family Income

Decomposition for 1979-2003

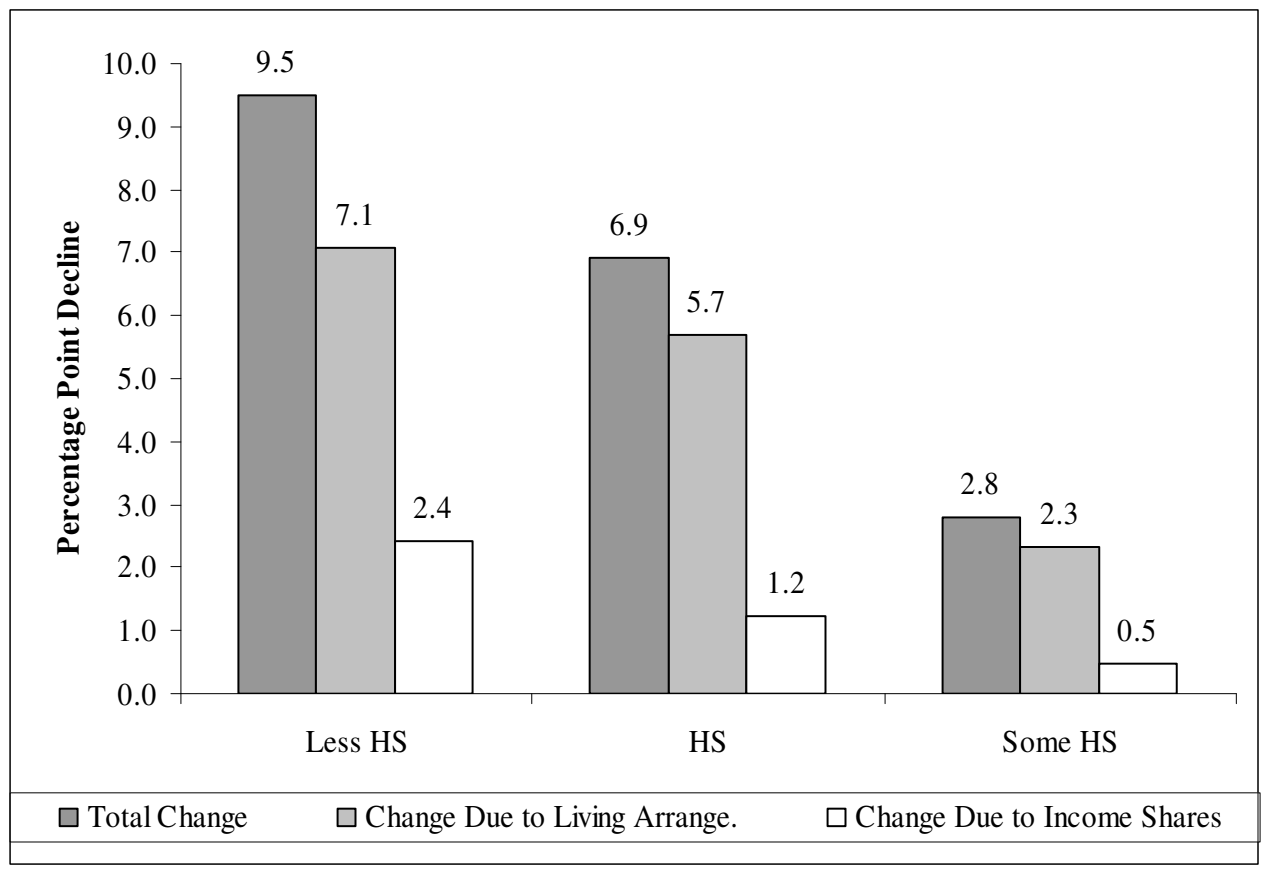

Decomposition for 1994-2003

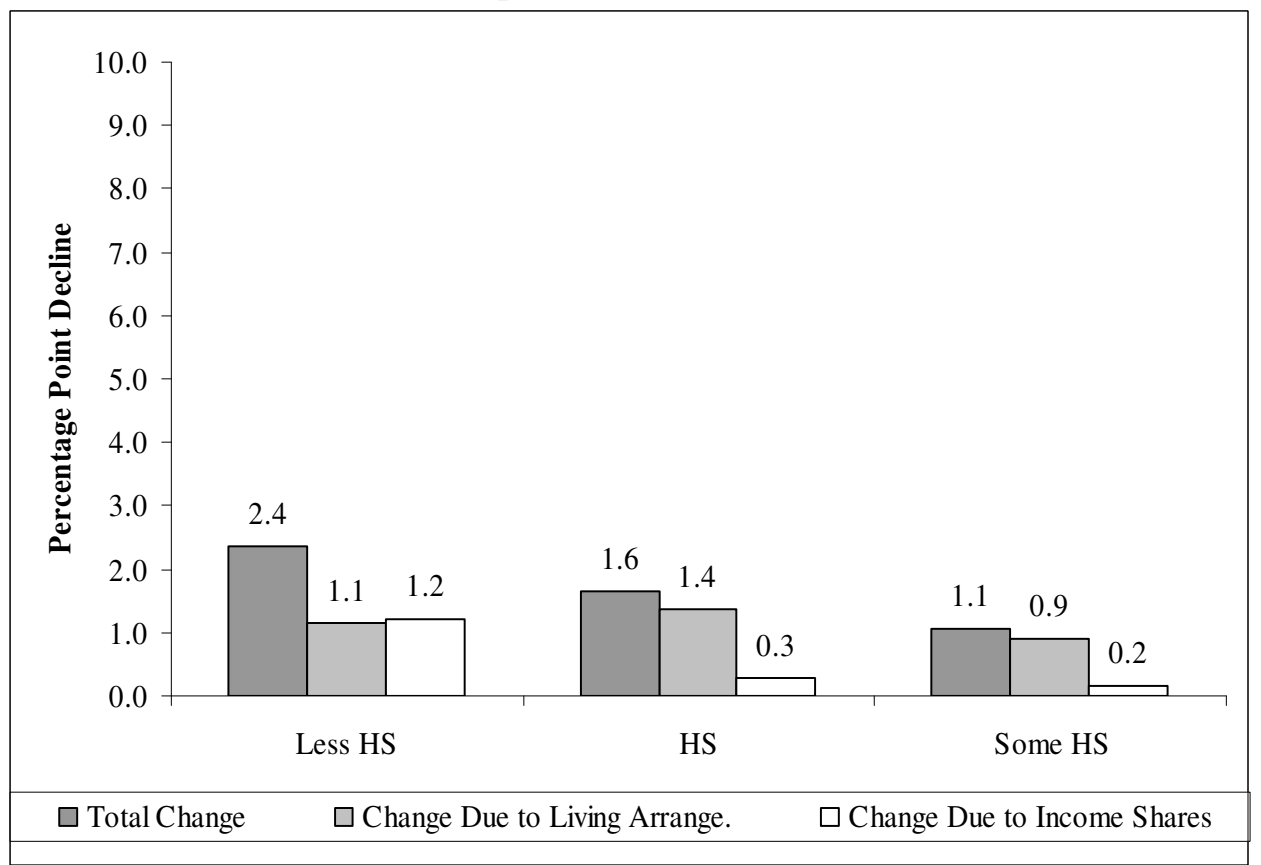


Figure 3: Components of Nuclear Family Income

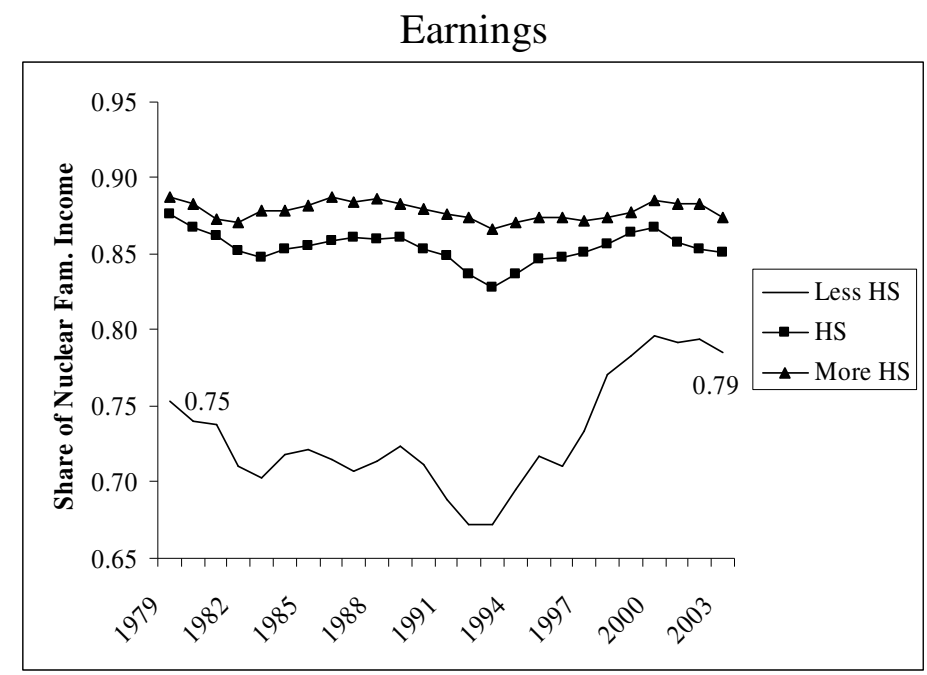

Means Test Transfers

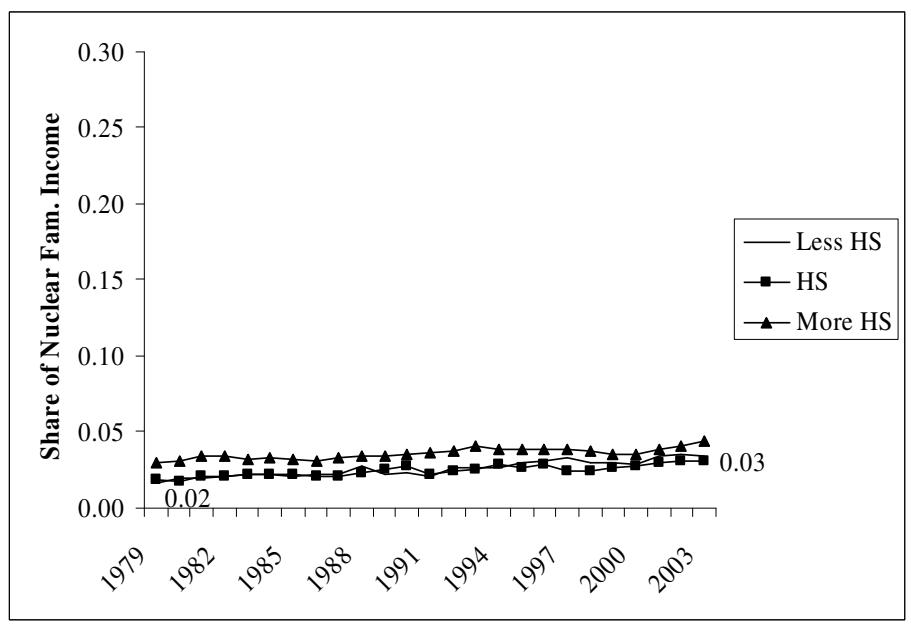

Financial Transfers, Alimony and Child Support

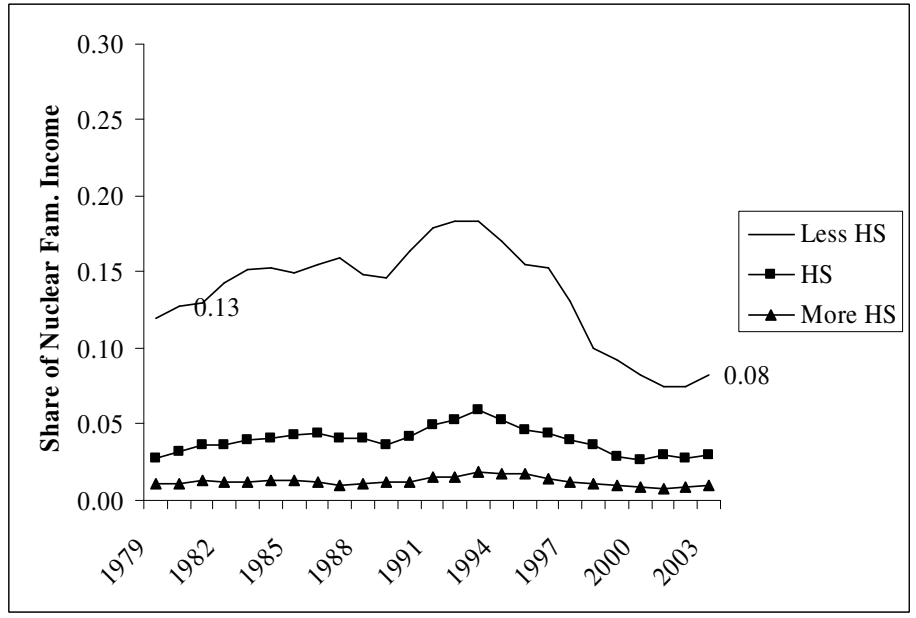

p. 38 


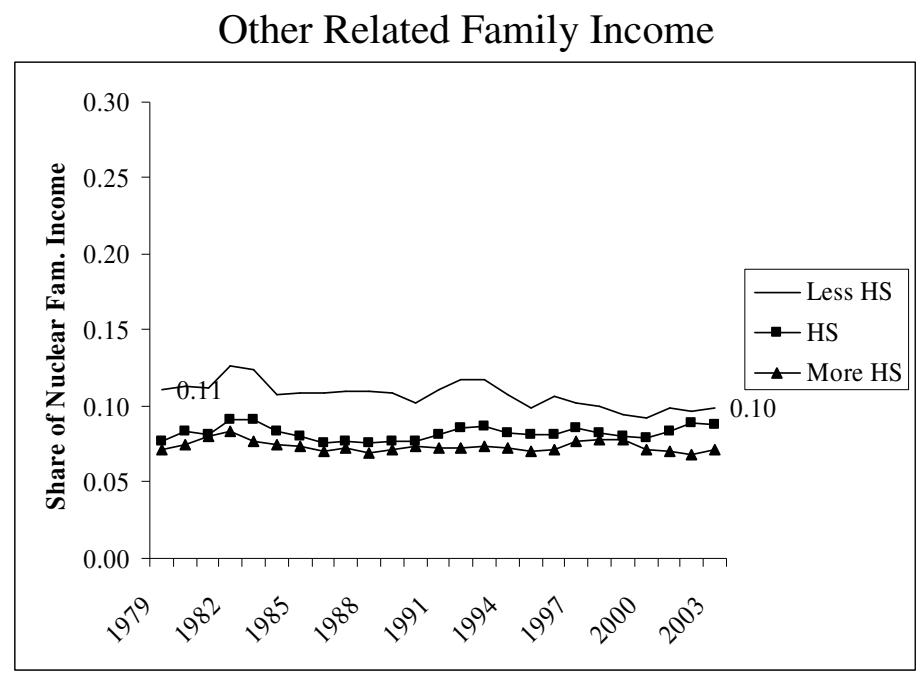

p. 39 
Figure 4: Regression-Adjusted Trends in the Fraction of Household Income by Source for All Women

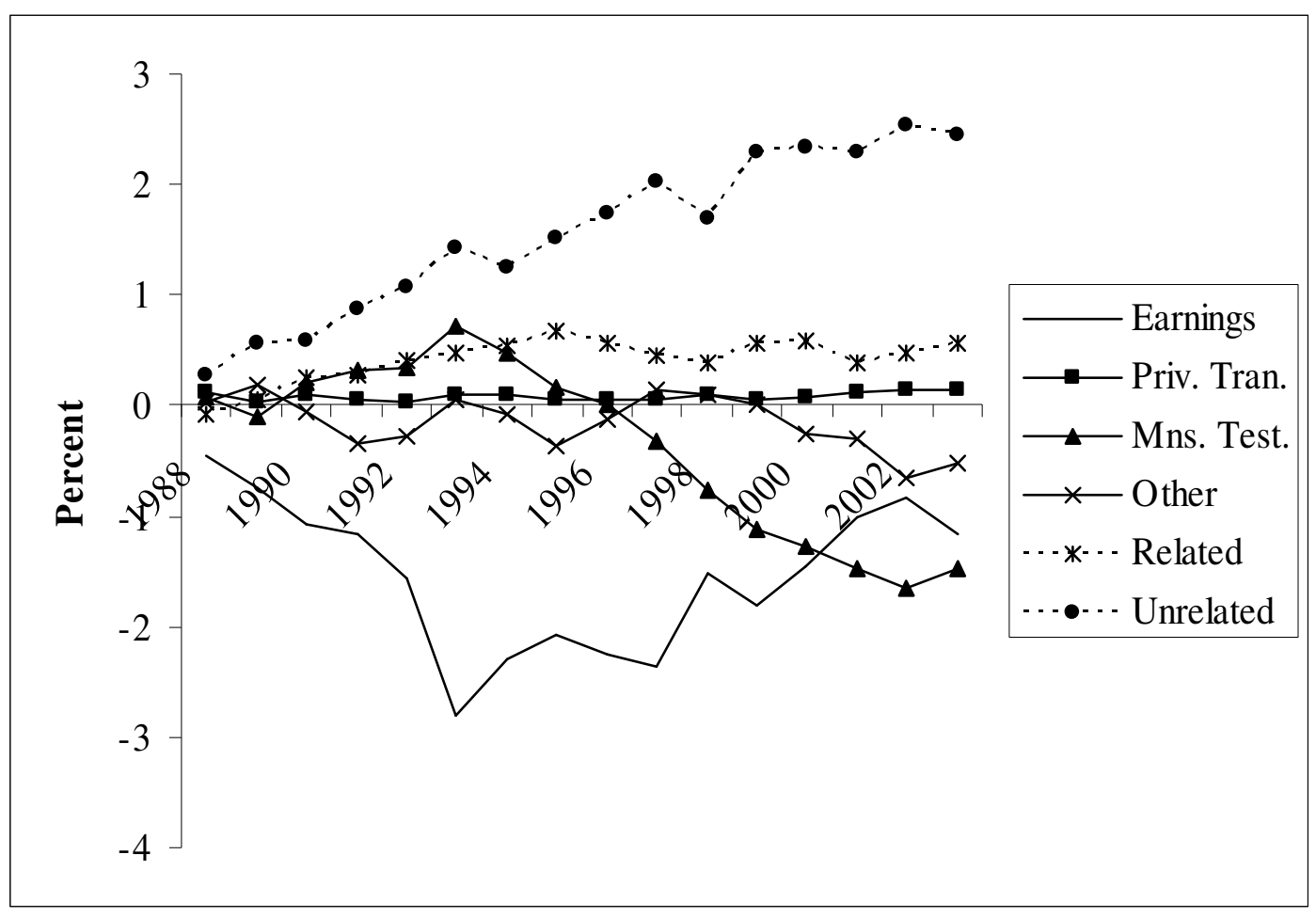

The estimates for these figures are based on equation 1 from the text. 


\section{Appendix}

Table A1: Decomposing Change in Nuclear Family Income Shares

\begin{tabular}{|c|c|c|c|}
\hline & Less $H S$ & $H S$ & More HS \\
\hline \multicolumn{4}{|l|}{ 1979-2003 Change } \\
\hline Total change in nuclear family income share & -9.49 & -6.93 & -2.80 \\
\hline Change due to changing living arrangements & -7.06 & -5.70 & -2.33 \\
\hline Change due to changing income shares & -2.43 & -1.23 & -0.46 \\
\hline Changes in living arrangements by household type & -7.06 & -5.70 & -2.33 \\
\hline married & -13.15 & -11.02 & -3.60 \\
\hline unmarried, nuclear family only & 1.20 & 0.63 & -0.85 \\
\hline unmarried, related and nuclear family only & 1.49 & 1.42 & 0.83 \\
\hline unmarried, any unrelated family & 3.39 & 3.28 & 1.28 \\
\hline Changes in income shares by household type & -2.43 & -1.23 & -0.46 \\
\hline married & -1.47 & -0.89 & -0.36 \\
\hline unmarried, nuclear family only & 0.00 & 0.00 & 0.00 \\
\hline unmarried, related and nuclear family only & -0.27 & -0.22 & -0.11 \\
\hline unmarried, any unrelated family & -0.68 & -0.12 & 0.01 \\
\hline \multicolumn{4}{|l|}{ 1994-2003 Change } \\
\hline Total change in nuclear family income share & -2.35 & -1.64 & -1.06 \\
\hline Change due to changing living arrangements & -1.15 & -1.37 & -0.91 \\
\hline Change due to changing income shares & -1.21 & -0.28 & -0.15 \\
\hline Changes in living arrangements by household type & -1.15 & -1.37 & -0.91 \\
\hline married & -1.14 & -4.41 & -2.02 \\
\hline unmarried, nuclear family only & -0.65 & 1.98 & 0.30 \\
\hline unmarried, related and nuclear family only & -0.42 & 0.12 & 0.09 \\
\hline unmarried, unrelated family with cohabitor & 1.31 & 1.14 & 0.85 \\
\hline unmarried, unrelated family, no cohabitor & -0.24 & -0.19 & -0.13 \\
\hline Changes in income shares by household type & -1.21 & -0.28 & -0.15 \\
\hline married & -0.23 & -0.31 & 0.00 \\
\hline unmarried, nuclear family only & 0.00 & 0.00 & 0.00 \\
\hline unmarried, related and nuclear family only & -0.36 & 0.17 & -0.03 \\
\hline unmarried, unrelated family, with cohabitor & -0.27 & -0.10 & 0.00 \\
\hline unmarried, unrelated family, no cohabitor & -0.35 & -0.04 & -0.12 \\
\hline
\end{tabular}


Table A2: OLS Model for Fraction of Household Income by Source

\begin{tabular}{|c|c|c|c|c|c|c|}
\hline \multirow[b]{2}{*}{ Regressor } & \multicolumn{4}{|c|}{ Nuclear family income sources } & \multicolumn{2}{|c|}{$\begin{array}{c}\text { Non-nuclear family } \\
\text { income sources }\end{array}$} \\
\hline & Earnings & $\begin{array}{l}\text { Private } \\
\text { transfers }\end{array}$ & $\begin{array}{l}\text { Means- } \\
\text { tested }\end{array}$ & Other & $\begin{array}{l}\text { Related } \\
\text { indiv. }\end{array}$ & $\begin{array}{c}\text { Unrelated } \\
\text { indiv }\end{array}$ \\
\hline \multirow[t]{2}{*}{ Unemployment rate } & -0.522 & 0.024 & 0.186 & 0.320 & 0.009 & -0.017 \\
\hline & $(0.044) * *$ & $(0.008) * *$ & $(0.022)^{* *}$ & $(0.030)^{* *}$ & $(0.020)$ & $(0.027)$ \\
\hline \multirow[t]{2}{*}{ Less than HS } & -15.427 & -0.141 & 8.675 & 2.037 & 3.026 & 1.830 \\
\hline & $(0.106)^{* *}$ & $(0.018) * *$ & $(0.053)^{* *}$ & $(0.071)^{* *}$ & $(0.049) * *$ & $(0.066) * *$ \\
\hline \multirow[t]{2}{*}{ HS degree } & -4.241 & -0.113 & 1.688 & 0.299 & 1.434 & 0.933 \\
\hline & $(0.075)^{* *}$ & $(0.013) * *$ & $(0.037)^{* *}$ & $(0.050)^{* *}$ & $(0.035)^{* *}$ & $(0.046) * *$ \\
\hline \multirow[t]{2}{*}{ Age } & -0.035 & -0.006 & 0.023 & 0.365 & -0.091 & -0.256 \\
\hline & $(0.004)^{* *}$ & $(0.001)^{* *}$ & $(0.002)^{* *}$ & $(0.003)^{* *}$ & $(0.002)^{* *}$ & $(0.002) * *$ \\
\hline \multirow[t]{2}{*}{ Enrolled in school } & 7.277 & 0.777 & -3.768 & 5.929 & -1.574 & -8.641 \\
\hline & $(0.144)^{* *}$ & $(0.025) * *$ & $(0.072)^{* *}$ & $(0.096)^{* *}$ & $(0.067)^{* *}$ & $(0.089) * *$ \\
\hline \multirow[t]{2}{*}{ Child present } & 1.002 & -0.226 & 3.346 & -0.416 & 2.262 & -5.968 \\
\hline & $(0.071)^{* *}$ & $(0.012) * *$ & $(0.036)^{* *}$ & $(0.048)^{* *}$ & $(0.033)^{* *}$ & $(0.044) * *$ \\
\hline \multirow[t]{2}{*}{ Married } & 26.019 & -0.395 & -5.616 & -5.412 & -2.688 & -11.908 \\
\hline & $(0.077)^{* *}$ & $(0.013) * *$ & $(0.038)^{* *}$ & $(0.051)^{* *}$ & $(0.036) * *$ & $(0.048) * *$ \\
\hline \multirow[t]{2}{*}{ Black } & -3.139 & -0.016 & 5.290 & -0.395 & 2.417 & -4.158 \\
\hline & $(0.107) * *$ & $(0.018)$ & $(0.054)^{* *}$ & $(0.072)^{* *}$ & $(0.050)^{* *}$ & $(0.067) * *$ \\
\hline \multirow[t]{2}{*}{ Hispanic } & -0.513 & -0.006 & 0.923 & -1.797 & 1.931 & -0.539 \\
\hline & $(0.117) * *$ & $(0.020)$ & $(0.059) * *$ & $(0.078)^{* *}$ & $(0.054)^{* *}$ & $(0.073) * *$ \\
\hline \multirow[t]{2}{*}{ Other } & -3.509 & 0.830 & 1.401 & -0.137 & 1.856 & -0.441 \\
\hline & $(0.165)^{* *}$ & $(0.028) * *$ & $(0.083)^{* *}$ & $(0.110)$ & $(0.076)^{* *}$ & $(0.103)^{* *}$ \\
\hline \multirow[t]{2}{*}{ Year-1988 } & -0.447 & 0.123 & 0.080 & 0.040 & -0.070 & 0.273 \\
\hline & $(0.204)^{*}$ & $(0.035)^{* *}$ & $(0.102)$ & $(0.137)$ & $(0.095)$ & $(0.127)^{*}$ \\
\hline \multirow[t]{2}{*}{ Year-1989 } & -0.747 & 0.031 & -0.091 & 0.190 & 0.049 & 0.567 \\
\hline & $(0.206)^{* *}$ & $(0.035)$ & $(0.103)$ & $(0.138)$ & $(0.095)$ & $(0.128)^{* *}$ \\
\hline \multirow[t]{2}{*}{ Year-1990 } & -1.085 & 0.103 & 0.207 & -0.063 & 0.253 & 0.585 \\
\hline & $(0.203)^{* *}$ & $(0.035) * *$ & $(0.102)^{*}$ & $(0.136)$ & $(0.094)^{* *}$ & $(0.126)^{* *}$ \\
\hline \multirow[t]{2}{*}{ Year-1991 } & -1.170 & 0.054 & 0.318 & -0.344 & 0.275 & 0.868 \\
\hline & $(0.202)^{* *}$ & $(0.035)$ & $(0.101)^{* *}$ & $(0.135)^{*}$ & $(0.094)^{* *}$ & $(0.126)^{* *}$ \\
\hline \multirow[t]{2}{*}{ Year-1992 } & -1.557 & 0.028 & 0.338 & -0.287 & 0.398 & 1.079 \\
\hline & $(0.208) * *$ & $(0.036)$ & $(0.104) * *$ & $(0.139)^{*}$ & $(0.097)^{* *}$ & $(0.130)^{* *}$ \\
\hline \multirow[t]{2}{*}{ Year-1993 } & -2.799 & 0.108 & 0.725 & 0.058 & 0.485 & 1.423 \\
\hline & $(0.202)^{* *}$ & $(0.035) * *$ & $(0.101)^{* *}$ & $(0.135)$ & $(0.094)^{* *}$ & $(0.126)^{* *}$ \\
\hline \multirow[t]{2}{*}{ Year-1994 } & -2.296 & 0.105 & 0.481 & -0.081 & 0.538 & 1.253 \\
\hline & $(0.199) * *$ & $(0.034) * *$ & $(0.100)^{* *}$ & $(0.133)$ & $(0.092) * *$ & $(0.124)^{* *}$ \\
\hline \multirow[t]{2}{*}{ Year-1995 } & -2.064 & 0.048 & 0.168 & -0.358 & 0.685 & 1.522 \\
\hline & $(0.200)^{* *}$ & $(0.034)$ & $(0.100)$ & $(0.134)^{* *}$ & $(0.093)^{* *}$ & $(0.125)^{* *}$ \\
\hline \multirow[t]{2}{*}{ Year-1996 } & -2.239 & 0.052 & 0.002 & -0.130 & 0.568 & 1.746 \\
\hline & $(0.201)^{* *}$ & $(0.035)$ & $(0.101)$ & $(0.135)$ & $(0.093) * *$ & $(0.125)^{* *}$ \\
\hline Year-1997 & -2.371 & 0.059 & -0.323 & 0.152 & 0.447 & 2.035 \\
\hline
\end{tabular}




\begin{tabular}{lcccccc} 
& $(0.206)^{* *}$ & $(0.035)$ & $(0.103)^{* *}$ & $(0.138)$ & $(0.095)^{* *}$ & $(0.128)^{* *}$ \\
Year-1998 & -1.521 & 0.107 & -0.769 & 0.100 & 0.386 & 1.696 \\
& $(0.211)^{* *}$ & $(0.036)^{* *}$ & $(0.106)^{* *}$ & $(0.141)$ & $(0.098)^{* *}$ & $(0.131)^{* *}$ \\
Year-1999 & -1.801 & 0.054 & -1.116 & 0.004 & 0.563 & 2.297 \\
& $(0.216)^{* *}$ & $(0.037)$ & $(0.108)^{* *}$ & $(0.144)$ & $(0.100)^{* *}$ & $(0.134)^{* *}$ \\
Year-2000 & -1.452 & 0.065 & -1.271 & -0.261 & 0.582 & 2.336 \\
& $(0.220)^{* *}$ & $(0.038)$ & $(0.110)^{* *}$ & $(0.147)$ & $(0.102)^{* *}$ & $(0.137)^{* *}$ \\
Year-2001 & -1.011 & 0.117 & -1.478 & -0.304 & 0.394 & 2.282 \\
& $(0.207)^{* *}$ & $(0.036)^{* *}$ & $(0.104)^{* *}$ & $(0.138)^{*}$ & $(0.096)^{* *}$ & $(0.129)^{* *}$ \\
Year-2002 & -0.833 & 0.134 & -1.661 & -0.647 & 0.482 & 2.525 \\
& $(0.197)^{* *}$ & $(0.034)^{* *}$ & $(0.099)^{* *}$ & $(0.132)^{* *}$ & $(0.091)^{* *}$ & $(0.123)^{* *}$ \\
Year-2003 & -1.174 & 0.145 & -1.465 & -0.528 & 0.566 & 2.457 \\
& $(0.196)^{* *}$ & $(0.034)^{* *}$ & $(0.098)^{* *}$ & $(0.131)^{* *}$ & $(0.091)^{* *}$ & $(0.122)^{* *}$ \\
\hline Mean of the dep var & 77.99 & 0.42 & 3.22 & 9.59 & 2.77 & 6.01 \\
Observations & 736,024 & 736,024 & 736,024 & 736,024 & 736,024 & 736,024 \\
R-squared & 0.200 & 0.010 & 0.110 & 0.040 & 0.040 & 0.160 \\
\hline
\end{tabular}

